ISSN 1112-9867

http://www.jfas.info

\title{
THEORETICAL STUDIES OF ETHYLNITROLIC ACID USING GAUSSIAN
}

\author{
S. Nikafshar ${ }^{1, *}$, Y. Moradi Mirazizi ${ }^{2}$, S. Nikafshar ${ }^{3}$ \\ ${ }^{1}$ Department of Applied Chemistry, Faculty of Chemistry, University of Tabriz, Tabriz, Iran \\ ${ }^{2}$ Pharmaceutical Research Laboratory, Departmen of Organic Chemistry, Faculty of \\ Chemistry, Isfahan University of Technology, Isfahan, Iran \\ ${ }^{3}$ Department of Organic Chemistry, Faculty of Chemistry, Razi University, Kermanshah, \\ Iran
}

Received: 27 May 2016 / Accepted: 28 December 2016 / Published online: 01 January 2017

\begin{abstract}
The tautomerism of all possible forms of ethylnitrolic acid was investigated theoretically in various environment including gas phase, ethanol, dimethyl sulfoxide (DMSO) and water. The calculations were carried out at DFT/B3LYP and $\mathrm{MP}_{2}$ of theory singly. It was found that, form of B eythynitrolic acid is the most stable isomer in the both gas phase and solvent. The activation energies for conversion of $\mathrm{A}$ to $\mathrm{R}$ and $\mathrm{B}$ to $\mathrm{A}$ in the gas phase and solvent using two methods DFT/B3LY and $\mathrm{MP}_{2}$ were obtained. Geometrical parameters of three isomers, $\mathrm{A}, \mathrm{B}$ and $\mathrm{R}$, were calculated by (DFT/B3LYP and $\left.\mathrm{MP}_{2}\right)$ in the gas phase and solvent. Vibrational analysis and acidity constants $\left(\mathrm{PK}_{\mathrm{a}}\right)$ of two isomers ( $\mathrm{A}$ and $\mathrm{R}$ ) were computed in the gas phase and water using DFT/B3LYP and $\mathrm{MP}_{2}$. After that, these quantities were evaluated with experimental values and it was determined that DFT/B3LYP is more accurate to obtain $\mathrm{PK}_{\mathrm{a}}$.
\end{abstract} Keywords: Tautomerism; ethylnitrolic acid; solvent effect; proton transfer reaction; acidity constant.

Author Correspondence, e-mail: S_nikafshar@yahoo.com doi: http://dx.doi.org/10.4314/jfas.v9i1.33 


\section{INTRODUCTION}

\subsection{Tautomerism}

Tautomerism is condition that one proton is added at one molecular site and then it is cut from another, so it is completely different from ionization [1]. This phenomenon is occurred in organic molecular although the relatively small portion of molecules which it can happen. Tautomers are various forms of a specific molecule that interconvert the location of a proton and pi bond by chemical reaction named tautomerization [2]. It is well clear that tautomerism is strongly described to the lone pair- lone pair repulsions. Inasmuch as the energy differences amid some tautomers are very low, their thermal energy may be so close to transfer from one tautomer to another at room temperature. Various solvents can directly affect to this transformation. Concentration of some tautomers are low, since they cannot be detected by experimental studies. Thus between the experimental and theoretical studies on tautomerism process are still competing works in molecular biology and chemistry.

Sorbic acid and sodium nitrate are currently used as food additives especially in food products [3]. As an unsaturated fatty acid, sorbic acid may react with nitrate to form antimicrobial compounds genotoxic activity against bacteria. Products with genotoxic activity turned out by the reaction of nitrate with sorbate include ethylnitrolic acid and 1,4-dinitro 2-methyl pyrrole. Ethylnitrolic acid is highly mutagenic in the "rec" assay and the Salmonella forward-mutation assay, but has less activity in the Salmonella/microsome test. In addition, the compound has strong antibacterial activity in the culture media, but not in the food. It is volatile by steam distillation and it is degraded to form dinitrogen oxide and acetic acid [4]. Needles to say that study of various forms of this material and calculation Ethylnitrolic acid is interesting compound because it can have different tautomers. In the present work, authors report the results about proton transfer reaction and tautomerism of Ethylnitrolic acid in the gas form and solution. In this study, fourteen tautomers have been subjected to two types of calculation: DFT/B3LYP and MP2.

\subsection{Computational details}

All calculations at this work were performed on a personal computer by means of GAUSSIAN 09 program package [5]. The second-order Moller-Plesset ( $\left.\mathrm{MP}_{2}\right)$ and density 
functional theory (DFT) calculations have been performed using 6-311++ G(d,p) basis set to investigate the tautomerism of all five tautomers of ethylnitrolic acid (ENA) in the gas phase and in the solution. The geometry of ethylnitrolic acid (ENA) and its tautomers were upgraded at the second order Møller-Plesset perturbation theory (MP2) [6, 7] and Handy and et al vast range modified Version of The Becke's three parameter exact exchange functional (B3) [8] mixed with gradient corrected correlation functional of Lee-Yang-Parr (LYP) of DFT method [9] and Moller-Plesset perturbation theory (MP2) of ab initio method with the 6-311++G* basis set have been employed to optimize the molecules[7, 10]. Harmonic vibrational frequencies were obtained at the same level of theory to verify the nature of minimum. To assess the effects of the polar solvent (ethanol, DMSO and water) on the geometries and relative stabilities of the tautomers of compounds A-E, we used the polarizable continuum model (PCM) [11] as accomplished in the Gaussian software suite of programs at $\mathrm{B} 3 \mathrm{LYP} / 6-311++\mathrm{G}(\mathrm{d}, \mathrm{p})$ and $\mathrm{MP} 2 / 6-311++\mathrm{G}(\mathrm{d}, \mathrm{p})$ level for the geometries optimized at the same level of theory. The natural bond orbital (NBO) technique was carried out at B3LYP/6-311++G(d, p) level by means of NBO program with Gaussian package. The interactions between filled and anti-bonding orbitals represent the deviation of the molecule from the Lewis structure can be used as the measure of replacement. Solvents effects are considered remedy increate reaction field method according the polarizable continuum model (PCM) [12-14]. Various polar solvents such as ethanol, DMSO and water were chosen to investigate the effects of solvent on the tautomerism. The geometry of transition states of the proton transfer reactions for converting the tautomers into another were characterized by QST2 method at the MP2/6-31 + G (d, p) level of theory. Similar calculations were carried out on the complex of water and tautomers, at the MP2 level of theory and the same basis category, to specify the transition state of proton transfer helped by water molecule. Moreover, natural bond orbital (NBO) analysis was performed on all of the optimized geometries obtained in this work $[15,16]$.

\section{RESULTS AND DISCUSSION}

Ethylnitrolic acid exists in different tautomeric forms in the gas phase and solution as they are 
shown in Figure 1. They can convert to various forms with proton transfer and unconjugated reactions. So fourteen isomers were evaluated in this study. As it is seen, Ethylnitrolic acid has many tautomeric forms, because it has electronegative atoms like nitrogen and oxygen that they produce multiple form (due to non-bonding pair electrons). The calculated enthalpy $(\mathrm{H})$ and Gibbs free activation energy all isomers were listed using two methods (DFT/B3LYP and $\mathrm{MP}_{2}$ ) in the Table 1 and Table 2. 


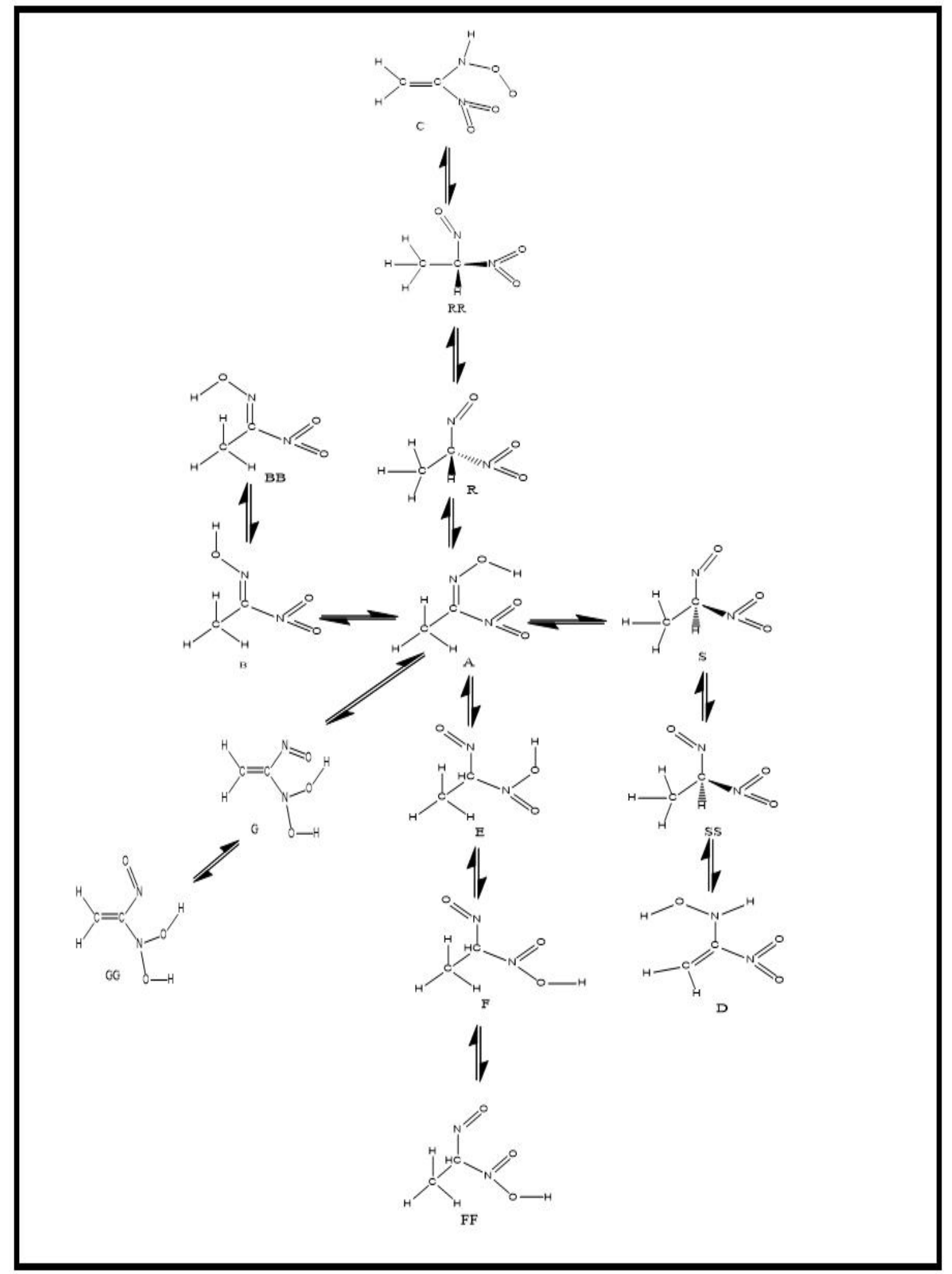

Fig. 1. Isomeration for the tautomers and rotamers of Ethylnitrolic acid (ENA) 


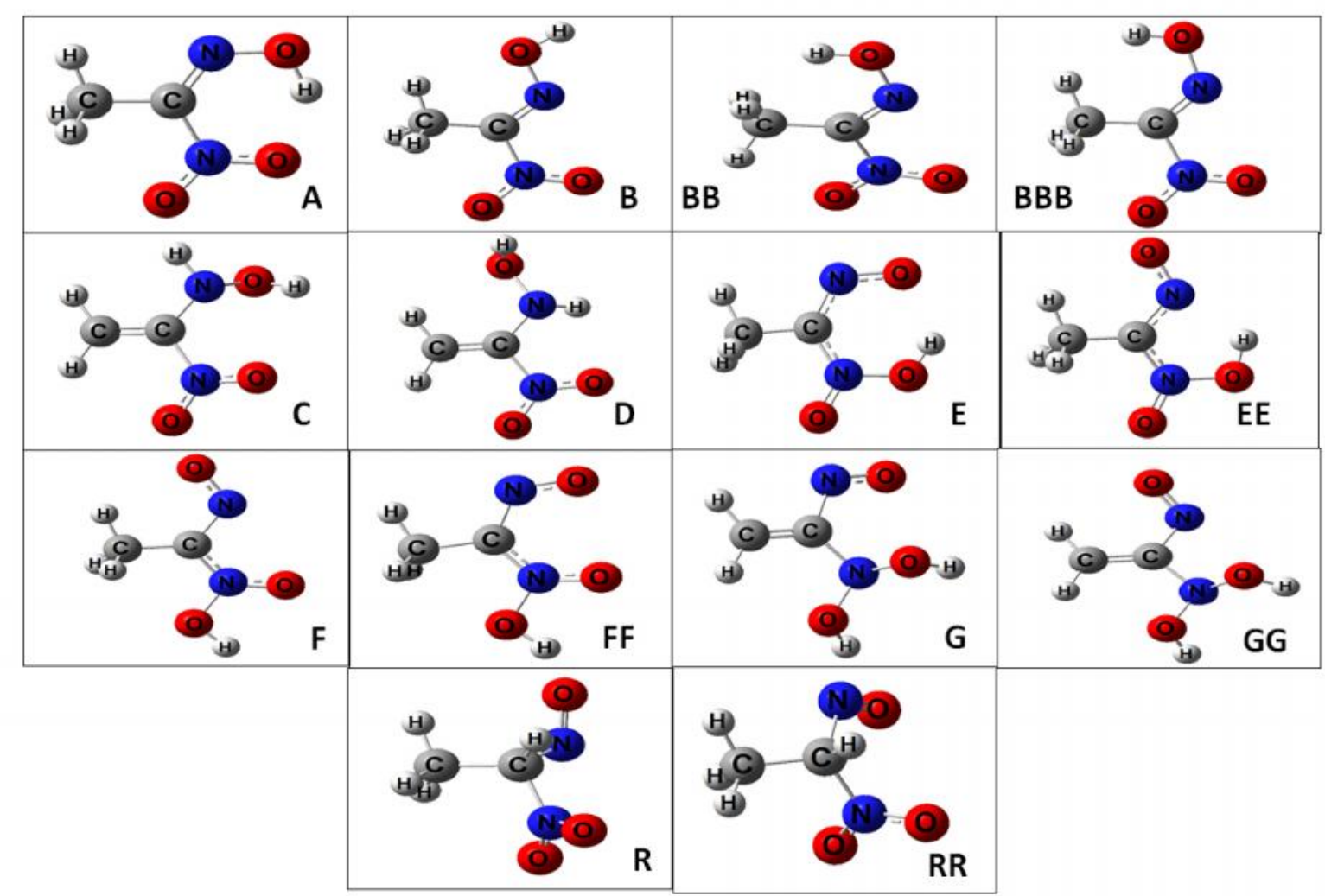

Fig.2. Optimized structure of transition states in the transfer reaction calculated at MP2 and DFT

Table 1. Calculated enthalpy and Gibbs free energy activation energy of all isomers using DFT/B3LYP method

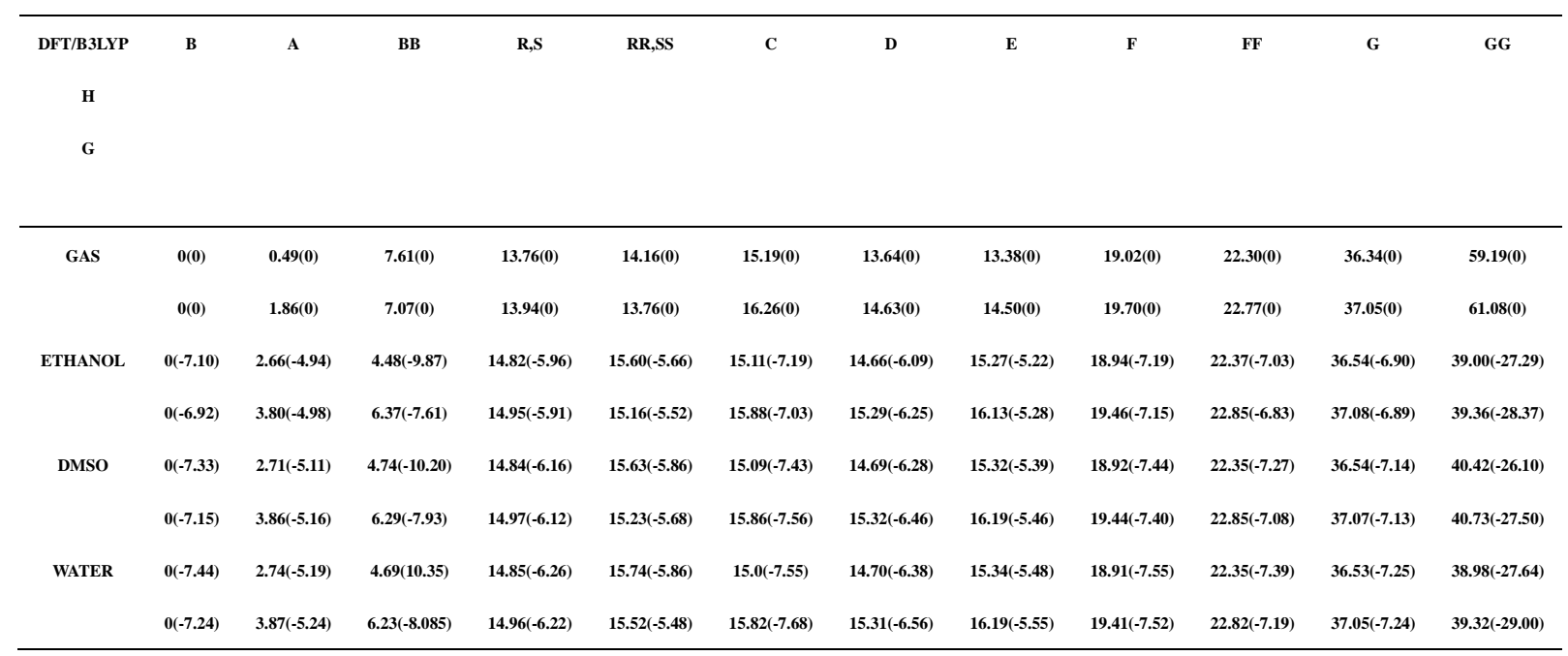


Table 2. Calculated enthalpy and Gibbs free energy activation energy of all isomers using $\mathrm{MP}_{2}$ method

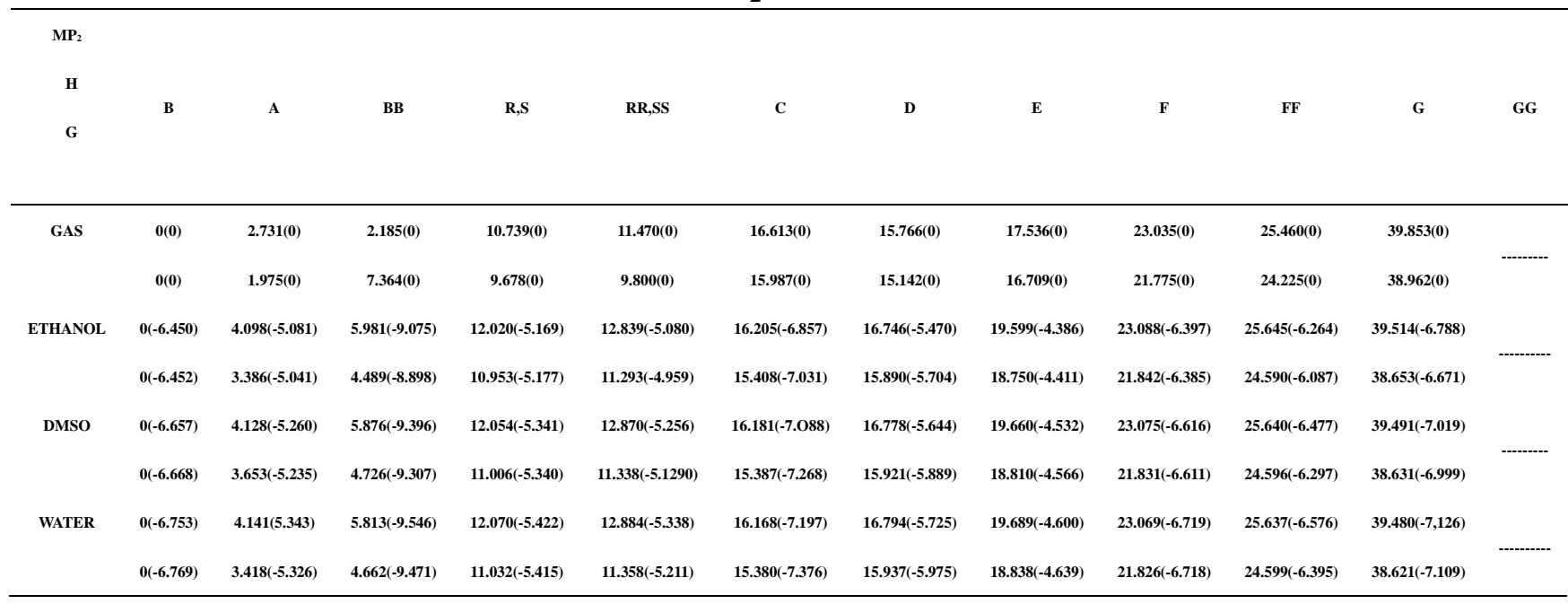

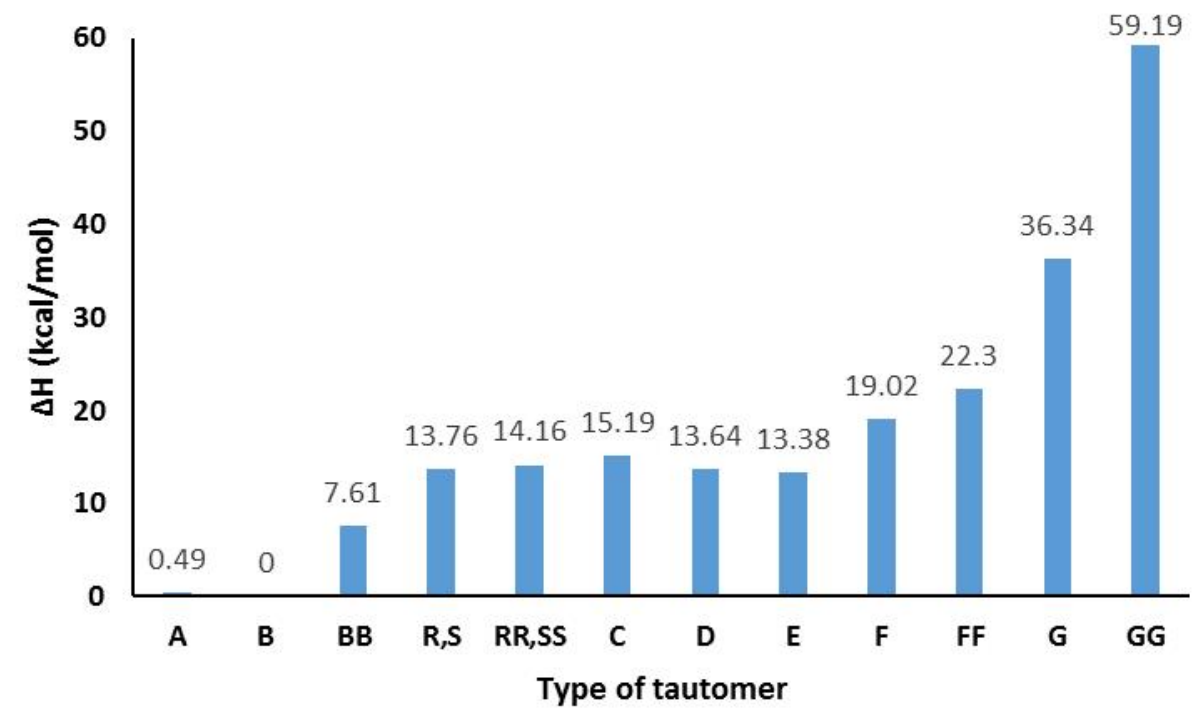

Fig.3. The calculated $\mathrm{H}$ of tautomers (in the gas phase) using DFT/B3LYP 


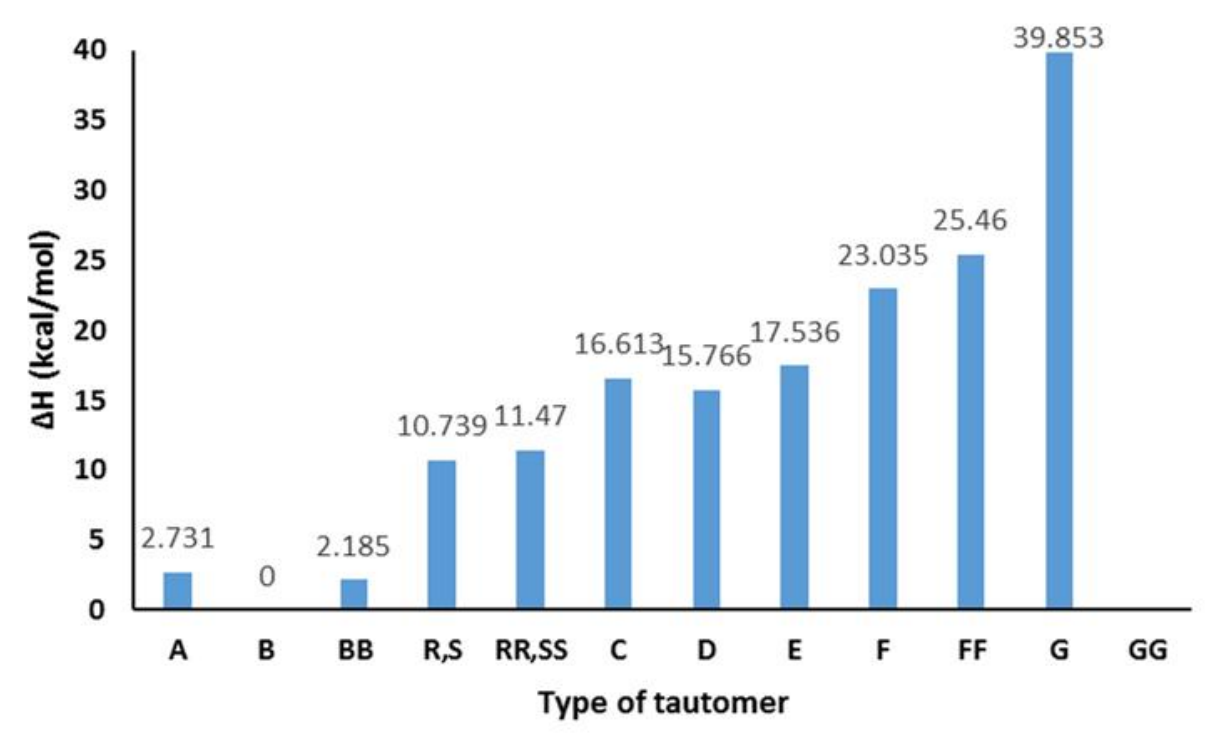

Fig.4. The calculated $\mathrm{H}$ of tautomers (in the gas phase) using $\mathrm{MP}_{2}$

The calculations at the DFT and $\mathrm{MP}_{2}$ reveal that the ethylnitrolic acid form, $\mathrm{B}$, is the most stable isomer in both gas phase and solution and GG, is the most unstable form. The order of stability of isomers according two methods were demonstrated in Figures 3 and 4. The order of stability in both methods are the same. It is worth mentioning that the calculated enthalpy of isomers in the DFT/B3YP are greater than $\mathrm{MP}_{2}$. For instance, the enthalpy of D from 13.64 in DFT/B3YP intensified to 15.766 in $\mathrm{MP}_{2}$.

Inasmuch as polarity variations amid tautomers can induce considerable changes in their relative energies in solutions, solvent effects are related to stability phenomena. For it, the PCM calculations were used to examine the solvent effects on tautomerism of ethylnitrolic acid. The obtained results from various solvents have been presented in Tables 1 and 2 and contrasted with those got from the gas phase. These comparisons divulge that except isomer GG in the DFT/3BYP and $\mathrm{G}$ in the $\mathrm{MP}_{2}$, quantities of enthalpy and Gibbs free energy activation of the rest were reduced from gas phase to solvents [17, 18].

In this section of paper, the proton transfer reaction for inter conversion of isomers in the two phases (gas and water) and the effect of solvent on this reaction is studied. In the proton transfer reaction of $\mathrm{A} \rightarrow \mathrm{R}$, the activation energies of reaction in the gas phase and water as solvent for proton transfer reaction were calculated using DFT and $\mathrm{MP}_{2}$ by $6-311+\mathrm{G}(\mathrm{d})$ basis function. According to equation (1), activation energy can be easily obtained. Where $\mathrm{H}$ is enthalpy, Ea is activation energy and $\mathrm{R}$ is gas constant. Computed activation energies of 
reaction $\mathrm{A} \rightarrow \mathrm{R}$ in the gas phase and water are tabulated in Table 3. Obtained data from two methods (DFT and $\mathrm{MP}_{2}$ ) were compared to each other. Although the activation energies from two methods are not identical, they show same order. In both methods the first activation energy $\left(E_{a 1}\right)$ is larger than second one $\left(E_{a 2}\right)$ and this procedure is completely reasonable. In the first reaction $(\mathrm{A} \rightarrow \mathrm{R})$ proton from oxygen was cut and then it is connected to carbon, but in the second reaction $(\mathrm{R} \rightarrow \mathrm{RR})$, proton only changed its position from forward of carbon to rear. For this reason, $\mathrm{E}_{\mathrm{a} 2}<\mathrm{Ea}_{1}$.

The effect of solvent on the activation energy of proton transfer reactions was also considered. It is shown that the activation energies of reactions in water are reduced. As regards water is a polar solvent, it is evident that water helps to proton transfer reaction and proton transfer will be faster in the present of water.

$$
\begin{array}{cc}
\mathrm{H}=\mathrm{Ea}-\mathrm{RT} & \mathrm{R}=0.001987 \mathrm{kcal} / \mathrm{K} \mathrm{mol} \\
\mathrm{Ea}=\mathrm{H}+\mathrm{RT}=\mathrm{H}+(0.001987) 298=\mathrm{H}+0.59(\mathrm{kcal} / \mathrm{mol})
\end{array}
$$

Table 3. Calculated activation energies of reaction $A \rightarrow R$ in the gas phase and water

\begin{tabular}{ccccc}
\hline \multirow{2}{*}{$\rightarrow \mathbf{R}$} & \multicolumn{2}{c}{ gas } & \multicolumn{3}{c}{ water } \\
\cline { 3 - 6 } & $\mathrm{E}_{\mathrm{a} 1}$ & $\mathrm{E}_{\mathrm{a} 2}$ & $\mathrm{E}_{\mathrm{a} 1}$ & $\mathrm{E}_{\mathrm{a} 2}$ \\
$\mathrm{DFT}$ & 62.24 & 49.07 & 44.10 & 31.81 \\
$\mathrm{MP}_{2}$ & 66.18 & 58.17 & 43.36 & 34.14 \\
\hline
\end{tabular}

*Note: Activation energies in $\mathrm{kcal} / \mathrm{mol}$

The activation energies in the gas phase for proton transfer reaction of $\mathrm{B} \rightarrow \mathrm{A}$ reaction in the gas phase were measured using DFT and MP2 methods by $6-311+\mathrm{G}(\mathrm{d})$ basis function [19]. The results of this measurement was reported in Table 4. Like previous reaction, the first activation energy is greater than second activation energy. As it is seen, the calculated activation energies in the reaction $\mathrm{B} \rightarrow \mathrm{A}$ are smaller than $\mathrm{A} \rightarrow \mathrm{R}$, because in the reaction of $\mathrm{B} \rightarrow \mathrm{A}$ proton only changed its direction and inclined to oxygen, but in the reaction of $A \rightarrow R$ proton was completely separated from oxygen and then connected to carbon. It goes without saying, the reaction of $\mathrm{B} \rightarrow \mathrm{A}$ is easier than $\mathrm{A} \rightarrow \mathrm{R}$. 
Table 4. Calculated activation energies of reaction $A \rightarrow R$ in the gas phase

\begin{tabular}{lll}
\hline $\mathbf{B} \rightarrow \mathbf{A}$ & & \multicolumn{1}{c}{ gas } \\
\cline { 2 - 3 } & Ea1 & Ea2 \\
\hline DFT & 39.36 & 38.86 \\
MP2 & 45.45 & 42.72 \\
\hline
\end{tabular}

*Note: Activation energies in $\mathrm{kcal} / \mathrm{mol}$

\subsection{Geometrical parameters}

The geometrical parameters of three selected isomers (B, A and R) that computed at the $\mathrm{MP}_{2}$ level of theory in the gas phase and different solvents were set down in Table 5. According to studies conducted, there is no experimental and theoretical report about the geometrical parameters of ethylnitrolic acid in the literature for comparison. The calculated $\mathrm{C}_{1}-\mathrm{N}_{2}$ bond length in $\mathrm{B}$, as the most stable isomer, $\mathrm{A}$ and $\mathrm{R}$ in the gas phase are 1.287, 1.299 and $1.508 \mathrm{~A}^{\circ}$, respectively that $\mathrm{B}$ has shortest $\mathrm{C}_{1}-\mathrm{N}_{2}$ bond length. Others bond lengths for mentioned isomers are various, and they depend the structure of isomer [20].

Solvent effect: Evaluation of the geometrical parameters of the optimized structure in the various solvents revealed that calculated geometrical parameters from the gas phase relatively are same with those from obtained in various solvents [21]. These parameters only differ in very small quantities. For example, for isomer of $\mathrm{R}$ the calculated bond lengths $\mathrm{N}_{3}-\mathrm{O}_{10}$ in the gas phase, ethanol, DMSO and water are 1.239, 1.241, 1.241 and 1.241 respectively. It is seen that the bond lengths mentioned in gas phase and solvent are very near to each other. It can be said that, solvent affects very low on the bond length. The conversion between isomers B, A and $\mathrm{R}$ was presented in Figure 5.<smiles>CON=C(N=O)C(C)(C)C</smiles>

B

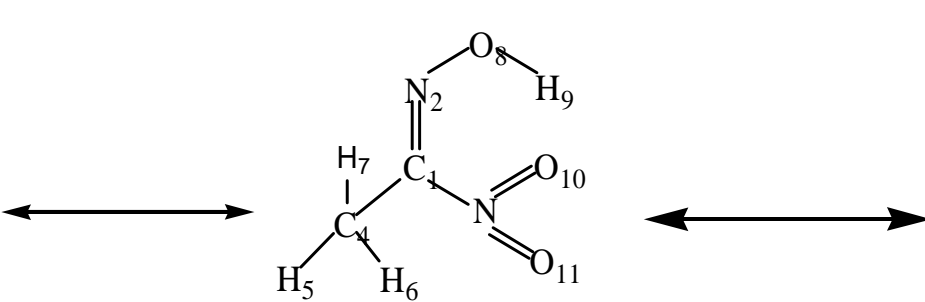

A

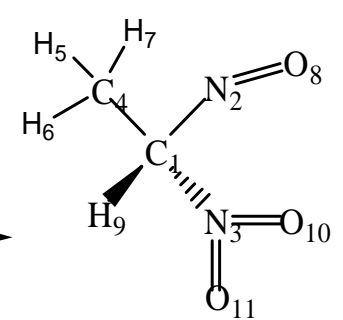

$\mathrm{R}$

Fig.5. Conversion between isomers B, A and R 
Table 5. Calculated geometrical parameters of isomers A, B and R in the gas phase and solution using the MP2/6-311+G(d) level of theory

\begin{tabular}{|c|c|c|c|c|c|c|c|c|c|c|c|c|}
\hline & \multicolumn{4}{|c|}{ B } & \multicolumn{4}{|c|}{$\mathbf{A}$} & \multicolumn{4}{|c|}{$\mathbf{R}$} \\
\hline & gas & ethanol & DMSO & water & gas & Ethanol & DMSO & water & gas & ethanol & DMSO & water \\
\hline $\mathrm{C}_{1}-\mathrm{N}_{2}$ & 1.287 & 1.288 & 1.288 & 1.289 & 1.299 & 1.298 & 1.298 & 1.298 & 1.508 & 1.503 & 1.503 & 1.503 \\
\hline $\mathrm{C}_{1}-\mathrm{N}_{3}$ & 1.483 & 1.480 & 1.480 & 1.480 & 1.473 & 1.473 & 1.473 & 1.473 & 1.491 & 1.492 & 1.492 & 1.492 \\
\hline $\mathrm{C}_{1}-\mathrm{C}_{4}$ & 1.486 & 1.484 & 1.484 & 1.484 & 1.492 & 1.490 & 1.490 & 1.490 & 1.513 & 1.512 & 1.512 & 1.512 \\
\hline $\mathrm{N}_{2}-\mathrm{O}_{8}$ & 1.399 & 1.392 & 1.391 & 1.391 & 1.362 & 1.369 & 1.369 & 1.369 & 1.227 & 1.228 & 1.228 & 1.228 \\
\hline $\mathrm{O}_{8}-\mathrm{H}_{9}$ & 0.977 & 0.979 & 0.979 & 0.979 & 0.992 & 0.992 & 0.992 & 0.992 & ----- & ---- & ------ & ----- \\
\hline $\mathrm{N}_{3}-0_{10}$ & 1.239 & 1.241 & 1.241 & 1.241 & 1.256 & 1.255 & 1.255 & 1.255 & 1.245 & 1.246 & 1.246 & 1.246 \\
\hline $\mathrm{N}_{3}-\mathrm{O}_{11}$ & 1.248 & 1.247 & 1.247 & 1.247 & 1.243 & 1.243 & 1.243 & 1.243 & 1.243 & 1.243 & 1.243 & 1.243 \\
\hline $\mathrm{C}_{4}-\mathrm{H}_{5}$ & 1.093 & 1.092 & 1.092 & 1.092 & 1.093 & 1.092 & 1.092 & 1.092 & 1.093 & 1.092 & 1.092 & 1.092 \\
\hline $\mathrm{C}_{4}-\mathrm{H}_{6}$ & 1.093 & 1.092 & 1.092 & 1.092 & 1.093 & 1.092 & 1.092 & 1.092 & 1.092 & 1.092 & 1.092 & 1.092 \\
\hline $\mathrm{C}_{4}-\mathrm{H}_{7}$ & 1.090 & 1.090 & 1.090 & 1.090 & 1.091 & 1.090 & 122.3 & 1.090 & 1.091 & 1.091 & 1.091 & 1.091 \\
\hline $\mathrm{C}_{1}-\mathrm{N}_{2}-\mathrm{O}_{8}$ & 110.9 & 111.2 & 111.2 & 111.2 & 122.8 & 122.3 & 122.2 & 122.2 & 114.5 & 114.8 & 114.8 & 114.8 \\
\hline $\mathrm{C}_{1}-\mathrm{N}_{3}-\mathrm{O}_{10}$ & 119.4 & 119.8 & 119.8 & 119.8 & 118.5 & 118.8 & 118.8 & 118.8 & 116.5 & 116.8 & 116.8 & 116.8 \\
\hline $\mathrm{C}_{1}-\mathrm{N}_{3}-\mathrm{O}_{11}$ & 114.8 & 115.3 & 115.3 & 115.3 & 117.2 & 117.2 & 117.2 & 117.2 & 117.3 & 117.8 & 117.8 & 117.8 \\
\hline $\mathrm{C}_{4}-\mathrm{C}_{1}-\mathrm{N}_{2}$ & 130.0 & 130.3 & 130.4 & 130.4 & 119.4 & 119.7 & 119.7 & 119.7 & 108.3 & 108.3 & 108.3 & 108.3 \\
\hline $\mathrm{N}_{2}-\mathrm{O}_{8}-\mathrm{H}_{9}$ & 101.8 & 102.6 & 102.6 & 102.6 & 108.5 & 108.7 & 108.8 & 108.8 & ---- & ----- & ------ & ------- \\
\hline $\mathrm{C}_{1}-\mathrm{N}_{2}-\mathrm{O}_{8}-\mathrm{H}_{9}$ & -179.9 & 179.9 & 179.9 & 179.9 & -0.0095 & 0.023 & 0.024 & 0.025 & ------ & ----- & ------- & ------- \\
\hline $\mathrm{N}_{3}-\mathrm{C}_{1}-\mathrm{N}_{2}-\mathrm{O}_{8}$ & -179.9 & -179.9 & -179.9 & -179.9 & -0.0036 & -0.015 & -0.015 & -0.015 & 0.998 & 1.655 & 1.679 & 1.689 \\
\hline
\end{tabular}

\subsection{Vibration Analysis}

To obtain the spectroscopic properties of ethylnitrolic acid and its isomers, frequency calculation analysis were carried out. It is notable that based on our literature search only one paper was found in which experimental vibrational modes were reported [22]. The obtained results in this paper are essentially different, and therefore no comparison was made.

Calculations were performed for a free molecule in vacuum. The prediction of the vibrational behavior of molecules was based on B3LYP/6-31++G(d,p). Two isomers were selected for vibration analysis (A and R). The data are shown in Table 6. 
Table 6. Calculated vibrational frequencies of two tautomeric forms (A and B) of ethylnitrolic acid in gas phase using the $6-311++\mathrm{G}(\mathrm{d}, \mathrm{p})$ basis set

\begin{tabular}{|c|c|c|c|c|c|c|}
\hline \multicolumn{4}{|r|}{ A } & \multicolumn{3}{|r|}{$\mathrm{R}$} \\
\hline No & Mp2 & B3LYP & Assignments & Mp2 & B3LYP & Assignments \\
\hline 1 & 3432.61 & 3324.61 & $v \mathrm{OH}$ & 3225.44 & 3166.78 & $\begin{array}{c}{\left[v\left(\mathrm{C}_{4}-\mathrm{H}_{5}+\mathrm{C}_{4}-\mathrm{H}_{6}\right)_{\mathrm{sym}}+\left(v \mathrm{C}_{4}-\mathrm{H}_{7}\right)\right]_{\text {asym }}} \\
+v \mathrm{C}_{1}-\mathrm{H}_{9}\end{array}$ \\
\hline 2 & 3223.93 & 3169.96 & {$\left[v\left(\mathrm{C}_{4}-\mathrm{H}_{5}+\mathrm{C}_{4}-\mathrm{H}_{6}\right)_{\mathrm{sym}}+\left(v \mathrm{C}_{4}-\mathrm{H}_{7}\right)\right]_{\mathrm{asym}}$} & 3213.67 & 3150.96 & $v\left(\mathrm{C}_{4}-\mathrm{C}_{5}+\mathrm{C}_{4}-\mathrm{H}_{6}\right)_{\text {asym }}$ \\
\hline 3 & 3200.51 & 3127.13 & $v\left(\mathrm{C}_{4}-\mathrm{C}_{5}+\mathrm{C}_{4}-\mathrm{H}_{6}\right)_{\text {asym }}$ & 3157.28 & 3123.95 & $v \mathrm{C}_{1}-\mathrm{H}_{9}$ \\
\hline 4 & 3115.90 & 3068.39 & $v\left(\mathrm{C}_{4}-\mathrm{H}_{5}+\mathrm{C}_{4}-\mathrm{H}_{6}+\mathrm{C}_{4}-\mathrm{H}_{7}\right)_{\mathrm{SYM}}$ & 3118.72 & 3077.21 & $v\left(\mathrm{C}_{4}-\mathrm{H}_{5}+\mathrm{C}_{4}-\mathrm{H}_{6}+\mathrm{C}_{4}-\mathrm{H}_{7}\right)_{\mathrm{SYM}}$ \\
\hline 5 & 1746.76 & 1640.47 & $\begin{array}{c}v \mathrm{C}_{1}-\mathrm{N}_{2}+v\left(\mathrm{~N}_{3}-\mathrm{O}_{10}+\mathrm{N}_{3}-0_{11}\right)_{\mathrm{ASYM}^{+}} \\
\delta \mathrm{C}_{4} \mathrm{H}_{5} \mathrm{H}_{6}+\mathrm{P} \mathrm{C}_{4}-\mathrm{H}_{7}\end{array}$ & 1791.08 & 1699.75 & $v \mathrm{~N}_{2}-\mathrm{O}_{8}+\tau \mathrm{C}_{1}-\mathrm{H}_{9}$ \\
\hline 6 & 1613.77 & 1622.15 & $\mathrm{P} \mathrm{OH}+v \mathrm{~N}_{3}-\mathrm{O}_{11}$ & 1538.47 & 1643.90 & $v\left(\mathrm{~N}_{3}-0_{10}+\mathrm{N}_{3}-0_{11}\right)_{\text {assy }}+\mathrm{P} \mathrm{C}_{1}-\mathrm{H}_{9}$ \\
\hline 7 & 1522.68 & 14.9918 & $\left(\mathrm{P} \mathrm{OH}+\delta \mathrm{C}_{4} \mathrm{H}_{5} \mathrm{H}_{6}\right)_{\mathrm{ASYM}}$ & 1531.73 & 1515.42 & $\delta \mathrm{C}_{4} \mathrm{H}_{5} \mathrm{H}_{6}$ \\
\hline 8 & 1510.43 & 1496.54 & $\left(\mathrm{P} \mathrm{OH}+\delta \mathrm{C}_{4} \mathrm{H}_{5} \mathrm{H}_{6}\right)_{\mathrm{SYM}}$ & 1520.00 & 1504.40 & $\tau \mathrm{C}_{4} \mathrm{H}_{5} \mathrm{H}_{6}+\delta \mathrm{C}_{4} \mathrm{H}_{5} \mathrm{H}_{7}+\delta \mathrm{C}_{4} \mathrm{H}_{6} \mathrm{H}_{7}$ \\
\hline 9 & 1501.89 & 1495.09 & $\tau \mathrm{C}_{4} \mathrm{H}_{5} \mathrm{H}_{6}+\delta \mathrm{C}_{4} \mathrm{H}_{5} \mathrm{H}_{7}+\delta \mathrm{C}_{4} \mathrm{H}_{6} \mathrm{H}_{7}$ & 1456.16 & 1431.61 & $\omega \mathrm{CH}_{3}$ \\
\hline 10 & 1462.06 & 1440.46 & $\omega \mathrm{CH}_{3}$ & 1372.70 & 1395.73 & $\begin{array}{c}\mathrm{POH}+v\left(\mathrm{~N}_{3}-\mathrm{O}_{10}+\mathrm{C}_{1}-\mathrm{N}_{3}\right)_{\mathrm{ASYM}^{+}} \\
\tau \mathrm{C}_{1}-\mathrm{H}_{9}\end{array}$ \\
\hline 11 & 1341.19 & 1323.25 & $\mathrm{POH}+v\left(\mathrm{~N}_{3}-0_{10}+\mathrm{C}_{1}-\mathrm{N}_{3}\right)_{\mathrm{ASYM}}$ & 1349.09 & 1316.22 & $\tau \mathrm{C}_{1}-\mathrm{H}_{9}$ \\
\hline 12 & 1224.02 & 1190.27 & $v \mathrm{C}_{1}-\mathrm{N}_{3}+\mathrm{P} \mathrm{OH}$ & 1293.71 & 1261.78 & $\mathrm{P} \mathrm{C}_{1}-\mathrm{H}_{9}$ \\
\hline 13 & 1130.03 & 1131.43 & $v \mathrm{~N}_{2}-\mathrm{O}_{8}+\omega \mathrm{CH}_{3}$ & 1165.31 & 1129.65 & $\mathrm{P} \mathrm{C}_{4} \mathrm{H}_{5} \mathrm{H}_{6}$ \\
\hline 14 & 1072.01 & 1073.58 & $\mathrm{P} \mathrm{C}_{4} \mathrm{H}_{5} \mathrm{H}_{6}$ & 1123.91 & 1091.32 & $\tau\left(\mathrm{C}_{4} \mathrm{H}_{7}+\mathrm{C}_{4} \mathrm{H}_{5} \mathrm{H}_{6}\right)+\mathrm{P} \mathrm{C}_{1}-\mathrm{H}_{9}$ \\
\hline 15 & 1006.87 & 1006.29 & $\tau\left(\mathrm{C}_{4} \mathrm{H}_{7}+\mathrm{C}_{4} \mathrm{H}_{5} \mathrm{H}_{6}\right)$ & 1050.61 & 1027.21 & $\tau\left(\mathrm{C}_{4} \mathrm{H}_{6}+\mathrm{C}_{4} \mathrm{H}_{5} \mathrm{H}_{7}\right)+\tau \mathrm{C}_{1}-\mathrm{H}_{9}$ \\
\hline 16 & 857.79 & 867.98 & $\delta \mathrm{N}_{3} \mathrm{O}_{10} \mathrm{O}_{11}+v \mathrm{C}_{1}-\mathrm{N}_{3}+\mathrm{P} \mathrm{OH}$ & 885.42 & 869.10 & $\delta \mathrm{N}_{3} \mathrm{O}_{10} \mathrm{O}_{11}+\tau\left(\mathrm{C}_{4} \mathrm{H}_{5}+\mathrm{C}_{4} \mathrm{H}_{6} \mathrm{H}_{7}\right)$ \\
\hline 17 & 698.51 & 790.20 & $\tau \mathrm{OH}$ & 831.96 & 832.11 & $\delta \mathrm{C}_{1} \mathrm{~N}_{2} \mathrm{~N}_{3}+\tau\left(\mathrm{C}_{4} \mathrm{H}_{6}+\mathrm{C}_{4} \mathrm{H}_{5} \mathrm{H}_{7}\right)$ \\
\hline 18 & 689.39 & 748.44 & $\tau\left(\mathrm{C}_{4} \mathrm{H}_{5}+\mathrm{C}_{4} \mathrm{H}_{6}\right)+\tau \mathrm{C}_{1}-\mathrm{N}_{3}$ & 789.96 & 744.57 & $v \mathrm{C}_{1}-\mathrm{N}_{2}+\tau \mathrm{C}_{4} \mathrm{H}_{5} \mathrm{H}_{7}$ \\
\hline 19 & 655.35 & 650.12 & $v \mathrm{C}_{1}-\mathrm{C}_{4}+\delta \mathrm{C}_{1} \mathrm{~N}_{2} \mathrm{O}_{8}$ & 651.28 & 634.44 & $v \mathrm{C}_{1}-\mathrm{N}_{2}$ \\
\hline 20 & 567.58 & 562.03 & $v \mathrm{C}_{1}-\mathrm{N}_{3}$ & 545.48 & 528.29 & $\delta \mathrm{C}_{1} \mathrm{~N}_{3} \mathrm{O}_{10}$ \\
\hline 21 & 448.34 & 455.54 & $\delta\left(\mathrm{C}_{1} \mathrm{~N}_{3} \mathrm{O}_{10}+\mathrm{C}_{1} \mathrm{~N}_{2} \mathrm{O}_{8}\right)_{\text {asym }}$ & 497.04 & 478.41 & $v\left(\mathrm{C}_{1}-\mathrm{N}_{2}+\mathrm{C}_{1}-\mathrm{N}_{3}\right)_{\mathrm{ASYM}}$ \\
\hline 22 & 397.14 & 420.12 & $\tau \mathrm{C}_{1}-\mathrm{N}_{2}+\mathrm{P} \mathrm{C}_{4} \mathrm{H}_{5} \mathrm{H}_{6}$ & 352.13 & 346.44 & $\delta \mathrm{C}_{1} \mathrm{~N}_{2} \mathrm{C}_{4}$ \\
\hline 23 & 353.26 & 352.19 & $\mathrm{P} \mathrm{N}_{2}-\mathrm{O}_{8}+\mathrm{PC}_{1}-\mathrm{C}_{4}$ & 299.29 & 289.55 & $\mathrm{P} \mathrm{N}_{3}-0_{11}+\mathrm{P} \mathrm{C}_{1}-\mathrm{C}_{4}$ \\
\hline 24 & 323.19 & 318.99 & $\mathrm{P} \mathrm{N}_{3}-0_{11}+\mathrm{P} \mathrm{C}_{1}-\mathrm{C}_{4}$ & 231.64 & 208.53 & $\mathrm{P}\left(\mathrm{C}_{4}-\mathrm{H}_{5}+\mathrm{C}_{4}-\mathrm{H}_{6}+\mathrm{C}_{4}-\mathrm{H}_{7}\right)_{\mathrm{SYM}}$ \\
\hline 25 & 285.86 & 290.60 & $\tau\left(\mathrm{C}_{4}-\mathrm{H}_{5}+\mathrm{C}_{4}-\mathrm{H}_{6}\right)$ & 198.39 & 187.66 & $\delta \mathrm{C}_{1} \mathrm{~N}_{2} \mathrm{~N}_{3}$ \\
\hline 26 & 192.29 & 198.75 & $\mathrm{P}\left(\mathrm{C}_{4}-\mathrm{H}_{5}+\mathrm{C}_{4}-\mathrm{H}_{6}+\mathrm{C}_{4}-\mathrm{H}_{7}\right)_{\mathrm{SYM}}$ & 118.85 & 120.90 & $\tau \mathrm{N}_{2}-0_{8}$ \\
\hline 27 & 33.66 & 71.31 & $\mathrm{~T}\left(\mathrm{~N}_{3}-0_{10}+\mathrm{N}_{3}-0_{11}\right)$ & 57.87 & 50.01 & $\tau\left(\mathrm{N}_{3}-0_{10}+\mathrm{N}_{3}-0_{11}\right)$ \\
\hline
\end{tabular}

*Note: Subscript definitions: asym (asymmetric); sym (symmetric); $v$ (stretching); $\tau$ (out of plane bending); $\omega$ (wagging); $\rho$ (in-plane bending) $; \delta$ scissoring. And all frequencies in $\mathrm{cm}^{-1}$

The obtained frequency calculations were measure with experimental data. To some extent, they overlap to each other. For instance, stretching mode hydroxyl group for the A were illustrated at 3432.61 and $3324.61 \mathrm{~cm}^{-1}$ using $\mathrm{MP}_{2}$ and $\mathrm{B} 3 \mathrm{LYP}$, respectively. Literature showed that this frequency is $3281 \mathrm{~cm}^{-1}$. The C-N stretching mode of this isomer became 
visible at 1746.76 and $1640 \mathrm{~cm}^{-1}$ using $\mathrm{MP}_{2}$ and $\mathrm{B} 3 \mathrm{LYP}$, respectively which this frequency was gotten $1640 \mathrm{~cm}^{-1}$ by experimental measurement. The asymmetric stretching of nitro group of the $\mathrm{R}$ were found to be 1538.47 and $1643.90 \mathrm{~cm}^{-1}$ using $\mathrm{MP}_{2}$ and B3LYP, respectively. While frequency of this group was mentioned $1640 \mathrm{~cm}^{-1}$ in real experiment [22]. By analogy of obtained data from MP2 and B3LYP methods and experimental measurement, it is revealed that B3LYP is more precise to predict IR peak positions.

\subsection{Acidity constant}

A trend of a molecule to release its proton is defined as acidity constant $\left(\mathrm{PK}_{\mathrm{a}}\right)$. This parameter is directly related to the standard free energy $\left(\mathrm{G}^{0}\right)$ of the deprotonation reaction in aqueous solution according following equation [23]:

$$
P K a=\frac{\Delta G}{2.303 R 7}
$$

For estimation of deprotonation of a compound can be used the thermodynamic cycle according Figure (6) [24].

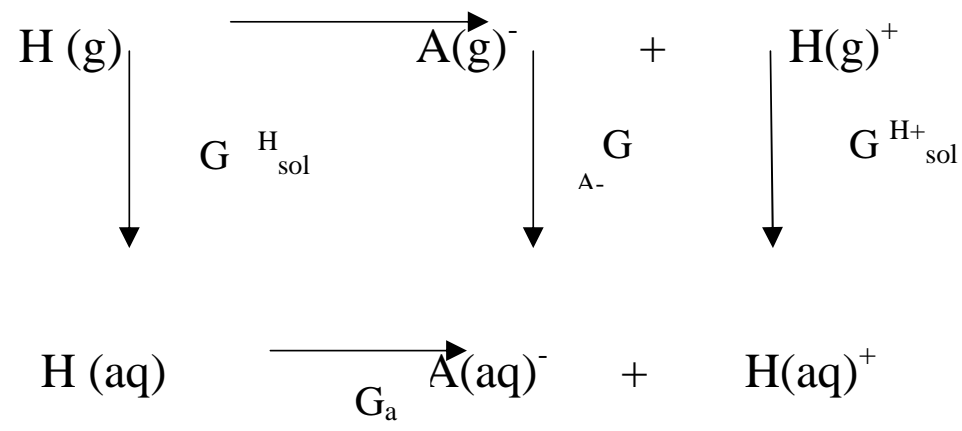

Fig.6. thermodynamic cycle

In the Figure 5, $\mathrm{G}_{\mathrm{g}}$ is the gas-phase deprotonation free energy of the molecular, and other parameters, $\mathrm{G}_{\mathrm{sol}}{ }^{\mathrm{AH}}, \mathrm{G}_{\mathrm{sol}}{ }^{\mathrm{A}-}$ and $\mathrm{G}_{\mathrm{sol}}{ }^{\mathrm{H}+}$ are the free energy of solvent of the protonated and deprotonated forms of the molecular and the proton, respectively. $G_{a}$, the fifth section of the cycle, is favorable free energy changes of deprotonation in solution. Since the total of free energies around the cycle must add to zero, $G_{a}$ is calculated from the other terms as it is 
shown in equation (3):

$$
\mathrm{G}_{\mathrm{a}}=\mathrm{G}_{\mathrm{g}}-\mathrm{G}_{\mathrm{sol}}^{\mathrm{AH}}+\mathrm{G}_{\mathrm{sol}}^{\mathrm{A}-}+\mathrm{G}_{\mathrm{sol}}^{\mathrm{H}+}
$$

Calculations according equation (3) for two isomers ( $\mathrm{A}$ and $\mathrm{R}$ ) in the gas phase and water were performed using $\mathrm{MP}_{2}$ and DFT methods. The results are presented below.

$\mathrm{A} \rightarrow \mathrm{A}^{-}+\mathrm{H}^{+}$

\section{DFT GAS}

$\mathrm{G}_{\mathrm{g}}=322.75 \mathrm{kcal} / \mathrm{mol} \quad \mathrm{PK}_{\mathrm{a}}=236.67$

\section{DFT in WATER}

$$
\begin{array}{lll}
\mathrm{G}=\mathrm{G}_{\mathrm{g}}-\mathrm{G}_{\mathrm{SOL}}^{\mathrm{AH}}+\mathrm{G}_{\mathrm{SOL}}^{\mathrm{A}-}+\mathrm{G}_{\mathrm{SOL}}^{\mathrm{H}+} \quad \mathrm{G}_{\mathrm{SOL}}^{\mathrm{AH}=-4.57} & \\
\mathrm{G}^{\mathrm{H}+}{ }_{\mathrm{SOL}}=-258.33 & \\
\mathrm{G}=11.08 \mathrm{kcal} / \mathrm{mol} \quad \mathrm{PK}_{\mathrm{a}}=8.12 &
\end{array}
$$

$\mathrm{MP}_{2}$ in the gas phase

$$
\mathrm{G}_{\mathrm{g}}=322.45 \mathrm{kcal} / \mathrm{mol} \quad \mathrm{PK}_{\mathrm{a}}=236.45
$$

\section{Mp2 in water}

$$
\begin{aligned}
& \mathrm{G}=\mathrm{G}_{\mathrm{g}}-\mathrm{G}_{\mathrm{SOL}}^{\mathrm{AH}}+\mathrm{G}^{\mathrm{A}-}{ }_{\mathrm{SOL}}+\mathrm{G}^{\mathrm{H}+}{ }_{\mathrm{SOL}} \quad \mathrm{G}^{\mathrm{AH}}{ }_{\mathrm{SOL}}=-4.46 \quad \mathrm{G}^{\mathrm{A}-}{ }_{\mathrm{SOL}}=-57.82 \\
& \mathrm{G}^{\mathrm{H}+}{ }_{\mathrm{SOL}}=-258.33 \\
& \mathrm{G}=10.76 \mathrm{kcal} / \mathrm{mol} \quad \mathrm{PK}_{\mathrm{a}}=7.89
\end{aligned}
$$

$\mathbf{R} \mathbf{R} \rightarrow \mathbf{R R}^{-}+\mathbf{H}^{+}$

DFT in the gas phase

$\mathrm{G}_{\mathrm{g}}=310.66 \mathrm{kcal} / \mathrm{mol} \quad \mathrm{PK}_{\mathrm{a}}=227.81$

\section{DFT in water}

$$
\begin{aligned}
& \mathrm{G}=\mathrm{G}_{\mathrm{g}}-\mathrm{G}_{\mathrm{SOL}}^{\mathrm{AH}}+\mathrm{G}^{\mathrm{A}-}{ }_{\mathrm{SOL}}+\mathrm{G}^{\mathrm{H+}}{ }_{\mathrm{SOL}} \quad \mathrm{G}^{\mathrm{AH}}{ }_{\mathrm{SOL}}=-5.82 \quad \mathrm{G}^{\mathrm{A}-}{ }_{\mathrm{SOL}}=-57.89 \\
& \mathrm{G}^{\mathrm{H}+}{ }_{\mathrm{SOL}}=-258.33 \\
& \mathrm{G}=0.26 \mathrm{kcal} / \mathrm{mol} \quad \mathrm{PK}_{\mathrm{a}}=0.19
\end{aligned}
$$

\section{Mp2 in the gas phase}

$$
\mathrm{G}_{\mathrm{g}}=314.75 \mathrm{kcal} / \mathrm{mol} \quad \mathrm{PK}_{\mathrm{a}}=230.81
$$

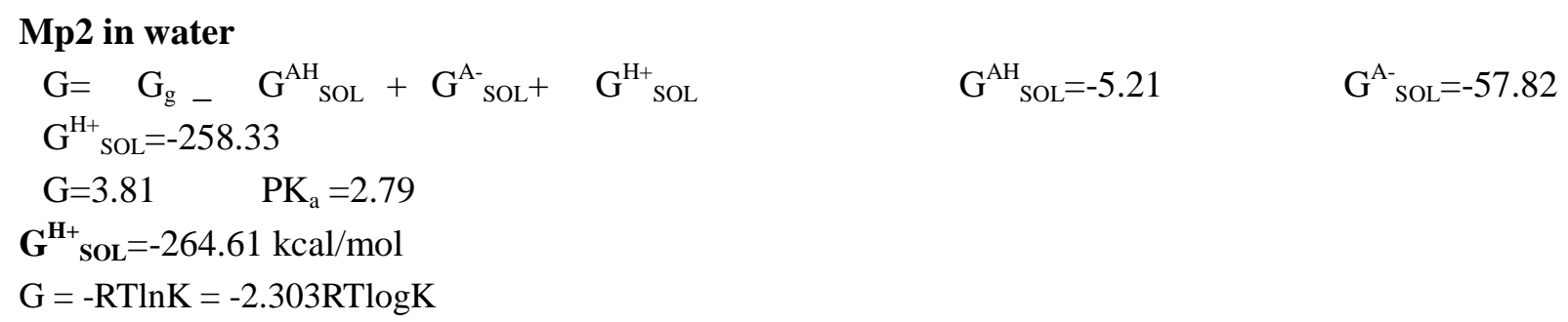


Table 7. The calculated $\mathrm{PK}_{\mathrm{a}} \mathrm{s}$ of isomers $\mathrm{A}$ and $\mathrm{R}$ in the gas phase and water using DFT and $\mathrm{MP}_{2}$ methods

\begin{tabular}{cccccc}
\hline & \multicolumn{2}{c}{$\mathbf{A}$} & \multicolumn{3}{c}{$\mathbf{R}$} \\
\cline { 2 - 5 } $\mathbf{P K}_{\mathbf{a}}$ & gas & water & gas & water \\
\cline { 3 - 6 } DFT & 236.67 & 8.12 & 227.81 & 0.19 \\
MP2 & 236.45 & 7.89 & 230.81 & 2.79 \\
\hline
\end{tabular}

As it is seen, the values of $\mathrm{PK}_{\mathrm{a}}$ in the gas phas are so high and they are not true and real. According to surveys taken of ethylnitrolic acid in water, only one paper reported $\mathrm{PK}_{\mathrm{a}}$ [25]. With comparison of obtained $\mathrm{Pk}_{\mathrm{a}} \mathrm{s}$ from experiment and calculations, $\mathrm{MP}_{2}$ method for calculation of $\mathrm{PK}_{\mathrm{a}}$ is more accurate. $\mathrm{PK}_{\mathrm{a}}$ ethylnitrolic acid in water from experimental method is 8.6 [25] and this value is closer than obtained $\mathrm{PK}_{\mathrm{a}}$ from DFT method.

\section{CONCLUSION}

This work demonstrates a development of the study of tautomerism of ethylnitrolic acid in the gas phase and solvent. The investigation revealed that isomer of $\mathrm{R}$ is the most stable form among various forms in both gas phase and solvent. The geometrical parameters of three isomers were obtained in several environments and discovered environment does not have significant effect to geometrical parameters. The vibration analysis provided vibrational frequencies of two isomers. Acidity constants of isomers in the gas phase and water were calculated and it was obtained that $\mathrm{PK}_{\mathrm{a}}$ in water is more rescannable than gas. Finally, with comparing calculated data using two methods (DFT and $\left.\mathrm{MP}_{2}\right)$ with experimental data, it can be said DFT method is more precise than $\mathrm{MP}_{2}$.

\section{ACKNOWLEDGEMENTS}

The authors greatly thank University of Tabrzi and Isfahan University of Technology for supporting the research reported in this article. 


\section{REFERENCES}

1. Lapworth A, Hann A. The mutarotation of camphorquinonehydrazone and mechanism of simple desmotropic change. J. Chem. Soc., 1902, 81, 1508-1519.

2. Anandan K, Kolandaivel P, Kumaresan R, Ab initio and DFT studies on tautomerism of indazole in gaseous and aqueous phases. J. Mol. Struc-THEOCHEM, 2004, 686(1-3), 83-89.

3. NAMIKI M, KADA T, Formation of Ethylnitrolic Acid by the Reaction of Sorbic Acid with Sodium Nitrite. Agric. Biol. Chem, 1975, 39(6) ,1335 - 1336.

4. Maga JA, Tu AT: Food additive Toxicplogy 1994.

5. Frisch M, Trucks G, Schlegel HB, Scuseria G, Robb M, Cheeseman J, Scalmani G, Barone V, Mennucci B, Petersson G, Gaussian 09. Inc, Wallingford, CT 2009, 200.

6. Fletcher BGD, Rendell AP, Sherwood P, A parallel second-order Møller-Plesset gradient. Mol. Phys, 1997, 91(3), 431-438.

7. Møller C, Plesset MS, Note on an Approximation Treatment for Many-Electron Systems. Phys. Rev. 1934, 46(7), 618-622.

8. Becke AD, Density-functional exchange-energy approximation with correct asymptotic behavior. Phys. Rev. A. 1988, 38(6).

9. Lee C, Yang W, Parr RG, Development of the Colle-Salvetti correlation-energy formula into a functional of the electron density. Phys. Rev. B. 1988, 37(2),785-789.

10. Wong MW, Wiberg KB, Frisch MJ, Solvent effects. 3. Tautomeric equilibria of formamide and 2-pyridone in the gas phase and solution: an ab initio SCRF study. J. Am. Chem. Soc. 1992, 114(5),1645-1652.

11. Miertuš S, Scrocco E, Tomasi J, Electrostatic interaction of a solute with a continuum. A direct utilizaion of $\mathrm{AB}$ initio molecular potentials for the prevision of solvent effects. Chem. Phys. 1981, 55(1), 117-129.

12. Tomasi J, Persico M, Molecular Interactions in Solution: An Overview of Methods Based on Continuous Distributions of the Solvent. Chem. Rev. 1994, 94(7), 2027-2094. 
13. Cancès E, Mennucci B, Tomasi J, A new integral equation formalism for the polarizable continuum model: Theoretical background and applications to isotropic and anisotropic dielectrics. J. Chem. Phys. 1997, 107(8), 3032-3041.

14. Barone V, Cossi M, Tomasi J, Geometry optimization of molecular structures in solution by the polarizable continuum model. J. Comput. Chem. 1998, 19(4), 404-417.

15. Reed AE, Weinstock RB, Weinhold F, Natural population analysis. J. Chem. Phys. 1985, 83(2), 735-746.

16. Reed AE, Curtiss LA, Weinhold F, Intermolecular interactions from a natural bond orbital, donor-acceptor viewpoint. Chem. Rev. 1988, 88(6), 899-926.

17. Chermhini A, Farrokhpour H, Teimouri A, Pourmoghaddas F, Theoretical studies on tautomerism of imidazole-2-selenone. Struct. Chem. 2013, 24(4), 1215-1227.

18. Beni AS, Dalirnasab Z, Teimouri A, Chermahini AN, Studies on tautomerism in the triazoline dione. Can. J. Chem. 2011, 89(11), 1387-1395.

19. Chermahini A, Teimouri A, Beni A, Theoretical studies on tautomerism of tetrazole 5-thion. Struct. Chem. 2011, 22(1), 175-181.

20. Chermahini AN, Dabbagh HA, Teimouri A, Theoretical studies on tautomerism of dihydropyrimidine tautomers. J. Mol. Struc. THEOCHEM. 2008, 857(1-3), 105-110.

21. Najafi Chermahini A, Nasr-Esfahani M, Dalirnasab Z, Dabbagh HA, Teimouri A, Theoretical studies on tautomerism of tetrazole derivatives by polarisable continuum method (PCM). J. Mol. Struc-THEOCHEM, 2007, 820(1-3), 7-11.

22. Morgan DJ. The infra-red and ultra-violet spectra of ethyl-nitrolic acid and its sodium salt. J. Appl. Chem. 1959, 9(4), 201-203.

23. Abedi M, Farrokhpour H, Acidity constants of some sulfur oxoacids in aqueous solution using CCSD and MP2 methods. J. Chem. Soc. Dalton Trans. 2013, 42(15), 5566-5572.

24. Lim C, Bashford D, Karplus M, Absolute pKa calculations with continuum dielectric methods. J. Chem. Phys. 1991, 95(14), 5610-5620.

25. Pérez-Prior MT, Manso JA, Gómez-Bombarelli R, González-Pérez M, Céspedes IF, García-Santos MP, Calle E, Casado J, Solvent effects in the decomposition reaction of 
some products formed by the reaction of sorbic acid with sodium nitrite:

1,4-dinitro-2-methylpyrrole and ethylnitrolic acid. J. Phys. Org. Chem. 2009, 22(5), 418-424.

How to cite this article:

Nikafshar S, Moradi Mirazizi Y, Nikafshar S. Theoretical Studies of Ethylnitrolic Acid Using Gaussian. J. Fundam. Appl. Sci., 2017, 9(1), 567-584. 